\title{
The Question of Divine Omnibenevolence: What does the Hebrew Bible Reveal about Yahweh's
} Nature?

\author{
Jonathan Faris, Religious Studies*
}

\begin{abstract}
The portrayal of God in the Hebrew Bible as a whole is overwhelmingly positive. However, this perception of the Hebrew Bible God, also known as Israel's patron deity, Yahweh, changes upon further examination of certain biblical passages that appear to portray a malicious, exceedingly violent Yahweh. These passages have caused significant debate among interpreters, with some defending his behavior while others cast Yahweh in a malevolent light. However, these questionable narratives can be better understood by a rather integral thread woven into the fabric of biblical tradition: Yahweh's covenantal relationship with his people. This unique relationship between patron god and people sets Israel apart from other ancient Near Eastern civilizations that had moody, passionate gods, such as Egypt and Babylonia. Yahweh made several covenants with the chosen people, and despite the Israelites' consistent, flagrant violations of the relationship as well as his being devoid of obligation to the group he voluntarily delivered from slavery in Egypt, he maintained his side of the covenant. This faithfulness exemplifies his emotional investment in his people, which manifests itself in divine pathos. Likewise, Yahweh shows care and protection for the Israelites, often in the form of Yahweh voluntarily coming down to earth to act (sometimes violently) on behalf of Israel. When morally ambiguous passages are viewed in light of these biblical contexts, we can attain a more comprehensive view of Yahweh that affirms his omnibenevolence.
\end{abstract}

\section{INTRODUCTION}

Should Yahweh in the Hebrew Bible be interpreted as a positive or negative deity? Through much of the Hebrew Bible, Yahweh is portrayed in a positive light, from his devotion to protecting the Israelites (his chosen people) to his blessings of the leaders of the Israelites; the numerous incidences of a "good god" attest to divine goodness. However, there are several notable narratives, namely the striking down of Uzzah in 2 Samuel 6 and the "martyrdom" of Nadab and Abihu in Leviticus 10, which some argue indicate a moody, even malevolent Yahweh. Scholars have wrestled with these morally ambiguous passages in the Hebrew Bible.

Interpreters like Abraham Heschel and Terence Fretheim have optimistic views of Yahweh, whereas scholars like David Penchansky and Eric Seibert reject divine goodness. The negative

\footnotetext{
* Jonathan Faris is a sophomore from Forest Grove, Oregon who is double majoring in Biology and Religious Studies. Currently, he is involved with the Cresko Lab at the University of Oregon, and is a Mathematics Tutor at the UO Teaching and Learning Center. He plans on pursuing a career in medicine or dentistry. Please direct correspondence to jfaris@uoregon.edu.
} 
depictions ascribed to Yahweh should not be construed as such because these rare instances where Yahweh's goodness appears compromised are a reflection of Yahweh's investment in the covenantal relationship between himself and Israel as well as Yahweh's care for his chosen people.

\section{NATURE OF THE COVENANT}

Throughout the Hebrew Bible, Yahweh enters into several covenantal relationships with biblical characters and groups, a majority of them involving the Israelites, his chosen people whom he delivered from the hands of the Egyptians. These include the Abrahamic covenant promising Abraham that his descendants would be blessed in return for faithfulness (Gen. 12), the Mosaic covenant established after Yahweh brought Israel out of Egypt that included the Ten Commandments as well as Mosaic Law (Exod. 19-24), and the Davidic covenant that promised David and his descendants claim of the royal throne (2 Sam. 7). These covenants are not contracts; a contract implies a legal agreement between two parties, whereas a covenant is a set of promises from both parties that reflects a personal, intimate relationship. Heschel illustrates the distinction between contract and covenant in light of his broader discussion of divine pathos by contrasting the coldness of a contract with the fellowship and loving involvement of Yahweh's covenant (Heschel, 10). This approachable Yahweh is atypical of many ancient gods and as a result, is more willing to sacrifice himself to keep the covenant intact.

Let us focus on the Mosaic covenant, since the exodus account is one of the most significant events in biblical tradition. Joseph had risen up the ranks of the Egyptian hierarchy to be Pharaoh's right-hand man, and as a result, influenced Pharaoh's decision to welcome the Israelites and give them fertile land to inhabit. However, when Pharaoh died and a new Pharaoh arose, the new Pharaoh had no memory of Joseph's relationship with Egyptian leadership and as a result, viewed the Israelites as a threat. He enslaved the Israelites and subjected them to forced labor. Exodus 2:24 marks the beginning of the Exodus account, when Yahweh "heard their groaning" and "remembered His covenants with Abraham, with Isaac, and with Jacob." After a series of ten plagues serving as a warning to Pharaoh against further persecution of the Israelites, Yahweh told Moses and Aaron that he would kill the firstborn of every household, and instructed each Israelite family to procure a year-old lamb on the tenth of the month, slaughter it at twilight on the fourteenth of the month, and put some of its blood on the doorposts and lintel of their houses (Exod. 12:3-13). Each house with the blood mark would be passed over and would escape death (Exod. 12:29). This event, along with the festival of unleavened bread, form the basis of the Jewish Passover holiday that commemorates Yahweh's deliverance of the Israelites from the oppressive grip of the Egyptians. Yahweh performed a violent act in the name of protection of both his people and their covenantal relationship. After the firstborns of the Egyptian households died, Pharaoh told the Israelites to leave his land, but this did not prevent him from pursuing them in their escape and ultimately being swallowed up by Red Sea (Exod. 14:26-29).

Yahweh then led them to their promised land (Canaan) while protecting them from its inhabitants (Canaanites, Philistines, and Amorites, to name a few). On the way to Canaan, when 
they were passing through the wilderness near Sinai, Yahweh descended to Moses at the mountain and delivered to him the Decalogue (Ten Commandments) as well as stipulations of the newly established Mosaic covenant (Exod. 19-24). In return, Yahweh would make Israel his "treasured possession" and a "priestly kingdom and a holy nation" (Exod. 19:5-6). This bond is often represented by marital imagery (Isa. 54:1-6) that personifies Israel as the Bride of Yahweh (Reddish, 782). Much like marriage, the covenantal relationship between Yahweh and Israel required investment from both parties. However, Yahweh was not obligated to initiate the covenant with the Israelites. He owed nothing to the Israelites and they owed everything back since without him, they would still be enslaved by Pharaoh. Instead, he drew himself into the "profane world" and took a risk by being personal and sharing in the fate of the world (Dozeman, 277). By nature of this unbalanced distribution of obligations, this divine covenant "implies that persons under covenant are capable of recognizing the fact that individually and corporately they have received benefits in their past that they have in no way earned" (Mendenhall, 1191). Yahweh delivered the Israelites from the Egyptians, promised them the land of Canaan, and vowed to provide protection from their enemies, all in return for loyalty and adherence to a basic set of rules. Therefore, the violent side of Yahweh is better understood in light of his committed, protective nature.

\section{BREAKDOWN IN COVENANTAL RELATIONSHIP}

Yahweh was clearly invested in his people, and despite the uneven obligations, faithfully fulfilled his end of the covenant. The Israelites inhabited Canaan and the previous occupants were driven out; the book of Joshua recounts the conquest of the land, highlighting events like the capture of Jericho, defeat of the Canaanite coalition of armies, and the allotment of land to the tribes of Israel (Josh. 5:13-19:51). However, Israel regularly turned their back on Yahweh and violated the covenant. This is especially apparent in the book of Judges, which chronicles the events in Canaan directly after the death of Joshua. The newly established tribes started interacting with each other, and were in constant contact with Yahweh through judges, who acted as Yahweh's emissaries but ultimately failed, leading the Israelites to act in a cyclical pattern signifying their inability to live up to the standards set forth in Deuteronomy that outlined how the Israelites should live in Canaan. The tribes repeatedly "did what was evil in the sight of the Lord" and were subsequently punished by Yahweh (Judg. 2:11-15). This offense came in the form of disobeying the law, worshipping other deities (like Baal), and refusing to listen to the prophets. Some scholars even suggest the prophet Isaiah did not expect to be heard, since he had his words recorded in a time when writing was not very widespread among Near Eastern societies due to limited education and social inequalities (Hays, 386).

The prophets were regarded as residing in the highest echelon of society due to their status as "kingmaker" and heightened standing as the intermediary between Yahweh and the people, yet their divinely-inspired calls to return to Yahweh were repeatedly swatted down. For example, in 1 Samuel 8, the Israelites clamored for a king, and despite Samuel's insistence that abuses and problems accompany kingship, the people were not persuaded (Hancock, 290-291). As "kingmaker", he gave the people what they wanted but warned them of the repercussions (Hancock, 296). While monarchy is typically portrayed in a negative light by the authors of the 
Hebrew Bible, some scholars argue the idea of a monarchy was desirable but the motivation behind wanting a king in the first place was contrary to conventional Israelite thought. In 1 Samuel, the people called for a king who could "[make Israel] like other nations, and that our king may govern us and go out before us and fight our battles" (1 Sam. 8:20). Yahweh, Israel's protector and king, would be “'deposed as king' because his role as military protector was to be transferred to Israel's human king” (Howard, 112). Due to Yahweh's longstanding role as Israel's king figure and the almost heretical attitude of the people, this reasoning for a king was erroneous on the Israelites' part, but the Israel monarchy did produce several good kings; King David, despite his faults, fit the mold of an ideal king through his leadership and devotion to Yahweh (Howard, 113). With the guidance of the prophet, the king could be a catalyst for adherence to the covenant; this illustrates the importance of prophetic leadership in Israel's history, especially its monarchal period.

There are considerable parallels between Moses and Samuel, including their miraculous births, distance from initial communities, divine calling, and actions as an intercessor on the Israelites' behalf (Hancock, 295). Additionally, just like Samuel, Moses acted as an advisor to fellow enforcers of the covenant. Moses, due to his subpar speaking ability (Exod. 4:10), relayed divine messages to his brother Aaron, who became his spokesperson to Pharaoh. Later on, however, Moses assumed responsibility of the primary prophetic duties while Aaron became the high priest; this shows his status as temporary advisor to Aaron and eventual advisor to the Israelite people. To illustrate, the Deuteronomistic Historian, the anonymous scholar during the Babylonian exile who compiled the books of the Deuteronomistic History (Joshua, Judges, 1 and 2 Samuel, 1 and 2 Kings), highlighted "the role of prophets in upholding the provisions of the Sinai covenant, concerns that are central for the DH [Deuteronomistic History]" (Hancock, 293). As Israel's history unfolded, the prophets were the enforcers of the covenant who advocated for maintaining the mutual relationship between the two parties (Yahweh and chosen people) and avoiding any strain put on the relationship by the actions of the Israelites. Even with the breakdown of the covenantal relationship despite the efforts of the prophets, Yahweh did not waver and continued to protect the Israelites, thus demonstrating his intrinsic benevolence.

Heschel offers a positive view of Yahweh from the perspective of the prophets, who had the most intimate relationship with Yahweh in ancient Israel and suffered like Yahweh. He asserts that the prophets understood God through his "intimate relation to the world" and most importantly, divine pathos (Heschel, 3). Yahweh was not the "God of the philosophers," who created the world and backed off, oblivious to the state of his creation (Heschel, 4). Instead, Yahweh displays reactive emotion to the actions of his people and cares about the welfare of his people, despite the periods of disobedience and unfaithfulness from the Israelites.

\section{POTENTIAL COMPROMISES OF YAHWEH'S OMNIBENEVOLENCE}

With a clear understanding of Yahweh's unique interest in the covenant as a backdrop, let us now consider the matter at hand: challenges to Yahweh's omnibenevolence. Some argue that there are notable episodes where Yahweh's all-goodness is compromised. David Penchansky, in 
his book What Rough Beast? Images of God in the Hebrew Bible, explores six narratives in the Hebrew Bible that he asserts depict Yahweh as a negative deity, contrary to the traditional, optimistic perspective on Yahweh. He suggests his audience analyze each of these narratives independently (focusing solely on the text itself and no other resources) as well as pretending Yahweh is a character in the story. The primary shortcoming of this approach is when he studies each passage, he disregards the rest of the Hebrew Bible and how this text, as a whole, portrays Yahweh. In his analysis of these passages, he suggests Yahweh is not omnibenevolent and appears insecure, irrational, vindictive, dangerous, malevolent, and abusive. Penchansky's petulant, aloof Yahweh is refuted by closer examination of the Hebrew Bible.

While Penchansky suggests Yahweh is driven by passion, he is instead driven by pathos. Yahweh's covenantal relationship with the Israelites implies this divine pathos. Due to his desire to maintain a good relationship with his people, there is intention behind his emotion; his emotion does not signal "drunkenness of the mind" as Heschel indicates (Heschel, 4). The authors of the Hebrew Bible contrast Yahweh with other ancient Near Eastern gods, who often exhibit passion in their own narratives. For example, in the Mesopotamian Myth of Atrahasis, Enlil (the storm god) decimates humanity with a flood and has a passionate tirade when Atrahasis survives (Herion, 991). These unreasoned actions characterize not only this Mesopotamian god, but Egyptian gods as well. They are often portrayed as unleashing anger in "petty tirades" when they are not pleased by their subjects (Herion, 994). They do not show restraint, in contrast to Yahweh who restrains his power to benefit humanity. After the flood in Genesis 6, Yahweh promises Noah that he would never flood the earth again (Gen. 9:11), showing his desire to restrain his power in order to benefit humanity's future.

In contrast to his self-imposed restriction of power in the flood narrative, Yahweh does not appear to restrain his power when he strikes down Uzzah in 2 Samuel 6. David, Yahweh's anointed king of Judah, has just become king of all Israel and conquered Jerusalem, which he subsequently makes his capital. He desires to make Jerusalem the religious as well as the political center of the kingdom, so he travels to Kiriath-jearim (where the ark was left in 1 Sam. 7) in order to get the ark of the covenant and bring it to Jerusalem. David brings along thirty thousand people, including two sons of a priest Abinadab, named Uzzah and Ahio. They load the ark onto an ox-cart and en-route to Jerusalem, the oxen shake the ark, causing Uzzah to reach out his hand to steady the ark. As a result, the "anger of the Lord was kindled against Uzzah" (2 Sam. 6:7). At first glance, this lashing-out seems excessive considering the good intent behind Uzzah's action in the absence of any clear explanation of his wrongdoing. As a priest, Uzzah likely knew all the Jewish law and history at the time, and if asked a question pertaining to his craft, he would answer in all of the acceptable ways (Long, 18). This leads us to view Uzzah as a pious man, a soul so devoted to following the commands set forth by Yahweh it seemed to be second nature. Thomas Long suggests the solution to this confusing narrative is in Uzzah's spontaneous reaction (Long, 18). The action did not seem in any way a product of Uzzah's quick reasoning due to the speed at which this event occurred, which indicates that Uzzah must have contemplated something negative similar to this happening, implying Uzzah's action was premeditated. If Uzzah believed Yahweh was omnipotent and who he said he was, Uzzah would not have reached out to steady the ark. An omnipotent Yahweh would not need the assistance of a 
newly-appointed priest to "dotter across the street", as Long puts it (Long, 18). Uzzah was so doubtful in Yahweh's power and control that he steadied the ark to cover all his bases, just in case Yahweh was not the omnipotent deity he himself had been professing. Therefore, Uzzah's weak faith was the reason for his death, not the malevolence of Yahweh.

Penchansky gives the example of the strange fire offered by two brothers (Nadab and Abihu) in Leviticus 10 as a case when Yahweh appears dangerous. These two recently ordained priests mixed incense with "strange fire" and offered it to the Lord (Lev. 10:1). As a result, they were consumed by the fire and died. While this may seem like a minor infraction that did not warrant capital punishment, the brothers did indeed violate the law. In Exodus 30:9, Yahweh instructs the priests to "not offer unholy incense." Penchansky himself references biblical critic Gnana Robinson, who suggests that, in context, "the phrases 'strange fire' and 'strange incense' are synonymous" and "both refer to the same thing, namely, the worship of "strange gods" (Penchansky, 57). The issue, then, is the impurity of the ritual. Purity and proper presentation was something Yahweh placed great importance on in Leviticus (Stackert, 576). Aaron's inexperienced sons either produced the fire for the wrong god or used unauthorized incense, both of which are covenantal infractions. Therefore, Yahweh's wrath was justified through his desire for the Israelites to respect the divine covenant, and was not a senseless violent act.

Penchansky's point about Yahweh being wrathful is true, but he overlooks the fact that his anger is a reaction, not an attribute. He and Seibert both make this fundamental error. They believe the instances when Yahweh's wrath seems unjustified reflect his character. Instead, human misconduct compels Yahweh to anger, and his divine anger takes several forms in the Hebrew Bible. The Hebrew word for divine anger in the Bible is 'ap, and two words used in conjunction with 'ap are hrrh and hậhôn (Herion, 990). The verb ḥrh (meaning "to burn") appears with 'ap as the subject in passages like Exodus 22:24 (“...my wrath will burn”) (Herion, 990). Additionally, the word hââon is a term for divine "rage" and literally means "burning"; it is used about three dozen times in association with 'ap (Herion, 990). This abundance of divine anger is justified due to the inspiration of his wrath. Israel's disobedience, evident from their "transgression of the covenant" (Josh. 7:1) and "pursuit of other gods" (Deut. 6:14-15), is almost always the subject of Yahweh's anger; therefore, ḥrh and hāân likely have "a specialized use designating the legitimate rage of a suzerain against a disobedient vassal" (Herion, 990). Divine anger is justified by the Israelites' constant violation of the covenant.

Seibert discusses narratives where Yahweh appears to behave disturbingly. In his first example, Seibert reasons the 613 Mosaic laws of Exodus, Leviticus, Numbers, and Deuteronomy portray Yahweh as a "Deadly Lawgiver" (Seibert, 17). He argues that the laws, especially the ones prescribing capital punishment, are "extreme" and "severe," concluding that God is too harsh on his people whom he is purported to be forgiving and kind towards (Seibert, 18). While these punishments do seem absurd at first glance, looking at them in the broader historical and cultural context reveals a different conclusion. There are many similarities between the Mosaic laws and Hammurabi's Code, an early law code in the ancient Near East. The idea of "an eye for an eye" (lex talionis) originates from this Babylonian code. Harsh punishments were common at the time and this was a culturally acceptable way of dealing with crime. The reason why we 
cringe at capital punishment in contemporary times is that our Western society is less severe than ancient Near East societies. As readers and scholars, our views reflect our cultural perceptions of crime and punishment. However, in order to understand the text fully, we need to be aware of the cultural chasm between our society and ancient Israelite society and view the laws in light of the time and cultural context in which it was written; this anachronism is where Seibert is incorrect.

\section{CARING AND PROTECTIVE YAHWEH}

By expressing his anger at the Israelites when they transgressed the covenant, Yahweh shows his care for them. For example, Yahweh exhibits anger and jealousy when his people worship other gods (1 Sam. 8:7-8). Just as a man feels jealous when another man flirts with his wife at a social gathering, Yahweh feels jealous when his bride (Israel) turns from him in favor of other gods. This type of jealousy is healthy, because indifference in this situation shows no tangible, emotional connection between the two subjects. There is somewhat of a rivalry between Yahweh and Canaanite deities like Baal, and they compete for the loyalty of Israel (van der Toorn, 916). Yahweh shows concern for the Israelites' well-being and showers blessings on those who follow his commandments (Deut. 28:1-14). In the second half of the book of Isaiah, Yahweh calls for the renewal of the covenant and how he will fulfill his side of the relationship, namely, the restoration of Israel after it was punished by the Assyrians for its sin. Yahweh asks the Israelites to "incline [their] ear and come to [him]" as part of his actions on behalf of Israel and delights in her return (Isa. 55:5, 62:4). He is genuinely concerned for the state of humanity and only exhibits anger when the sacred relationship between him and his beloved is broken.

One way Yahweh cares for the Israelite people is through his protection. This often comes in the form of military protection from other ancient Near Eastern cultures, like the Philistines and the Assyrians that were especially hostile to Israel during their infantile stages in the Deuteronomistic History as well as their exilic and post-exilic years. In the Divine Warrior narratives, the personal name for Israel's patron deity is Yahweh Zebaoth (or Sabaoth), which occurs 284 times in the Hebrew Bible and describes Yahweh's power and his command of heavenly hosts (Mettinger, 920). This term is mentioned mostly around discussion of Jerusalem temple theology during the time of the prophets and exists in close connection to the cherubim throne (composed of divine beings that attend to Yahweh) mentioned in 1 Samuel 4:4, 2 Samuel 6:2, and Isaiah 37:16 (Mettinger, 921-922). Through the temple connection, Yahweh is present on earth and on his throne in heaven simultaneously (Mettinger, 923). The significance of the Lord of Hosts is his willingness to descend to earth to protect his chosen people. Isaiah 19:16-17 says, "On that day the Egyptians will be like women, and tremble with fear before the hand that the Lord of Hosts raises against them. And the land of Judah will become a terror to the Egyptians; everyone to whom it is mentioned will fear because of the plan that the Lord of Hosts is planning against them." In Isaiah 37, Yahweh promises Hezekiah that he will preserve the remnant of Judah, and sends an angel to destroy the Assyrian king Sennacherib's army that is laying siege on Jerusalem. Yahweh is so concerned for the Israelites' welfare that he descends from heaven accompanied by his heavenly armies and honors the Davidic covenant that ensured 
David his descendants would inherit the kingship of Judah. This unique, caring relationship is uncharacteristic of ancient Near Eastern deities.

\section{YAHWEH'S SELF-SACRIFICE}

Like Heschel, Fretheim focuses on the prophets, but he looks at how the prophets, as representatives of Israel, bear the sins of the people and how their lives mirror the life of Yahweh (Fretheim, 139). He evaluates divine suffering and reinforces the idea that Yahweh suffers because of the breakdown in the covenantal relationship (Fretheim, 109). Yahweh calls for the Israelites' repentance because he does not enjoy exacting judgment on them. Also, when Yahweh bears those sins, he becomes weary from the burden; many verses illustrate this divine weariness, including Isaiah 7:13 ("you weary my God") and Jeremiah 15:6 ("You have rejected me', says the Lord... 'I am weary of relenting'”) (Fretheim, 140). Extending this idea, Fretheim asserts Yahweh's life is literally eroded as a result of bearing the people's sins. To support this, he analyzes Leviticus 17:11, which states that Yahweh has given the sacrificial blood to mankind for the atonement of their sins (Fretheim, 138). Yahweh, as the life-giver to the animals that are used for sacrifice, gives up part of himself so his people have the ability to repent and gain forgiveness. There comes a time when his long-suffering patience is at its end, and this is when judgment comes. In other words, "it is only because of God's willingness to continue to suffer as long as he has that the people continue to live" (Fretheim, 143). At the beginning of Isaiah (Isa. 1:2-9), Israel is criticized for its defection, and the "survival of even a remnant is already a mark of God's grace" (Williamson, 364). Yahweh, who has the power capable of judgment at any time, is so merciful that he chooses to delay judgment to give his people (whom he is emotionally bound to) a chance to repent using his own lifeblood.

\section{CONCLUSION AND THIS STUDY'S RELEVANCE TO FUTURE HEBREW BIBLE STUDY}

Yahweh's omnibenevolence is best demonstrated through his unique relationship with the Israelite people. Unlike other ancient Near Eastern deities, he does not exist to be appeased and does not lash out in unrestrained rage when his people flagrantly violate the covenant. Instead, he consistently honors the covenant even when the other party does not, which shows his investment in the Israelites. He is emotionally affected by the covenantal violations, but exhibits pathos in expressing his anger. This reasoned wrath in Yahweh's judgment is the result of his long-suffering patience and voluntary depletion of himself in order for the Israelites to have a chance at repentance and forgiveness. Lastly, Yahweh's care for his people is illustrated through his willingness to descend to earth to act on their behalf. Though in some situations Yahweh may appear malicious, the narrative in question cannot be taken independently from the rest of the Hebrew Bible because it is inherently woven into a larger framework that portrays Yahweh as long-suffering, yet forgiving, willing to overlook transgressions in order to allow his chosen people to return to him. This image of an omnibenevolent Yahweh is the one that should guide further exploration of the Hebrew Bible in a larger historical and religious context. 


\section{ACKNOWLEDGEMENTS}

I would like to thank Professor Andrew J. Riley of the University of Oregon's Religious Studies Department and Judaic Studies Program for his guidance and mentorship throughout the composition and revision process.

\section{REFERENCES}

Dozeman, Thomas B. "Exodus." Oxford Encyclopedia of Books of the Bible. Ed. Michael D. Coogan. 2011. Volume 1, 261-282. Print.

Fretheim, Terence. The Suffering of God: An Old Testament Perspective. Philadelphia: Fortress Press, 1984. Print.

Hancock, Rebecca S. "1 and 2 Samuel.” Oxford Encyclopedia of Books of the Bible. Ed. Michael D. Coogan. 2011. Volume 2, 287-305. Print.

Hays, Christopher B. "Isaiah.” Oxford Encyclopedia of Books of the Bible. Ed. Michael D. Coogan. 2011. Volume 1, 384-409. Print.

Herion, Gary A. "Wrath of God (OT).” Anchor Bible Dictionary. Ed. David Noel Freedman. 1992. Volume 6, 989-996. Print.

Heschel, Abraham J. The Prophets: Part II. New York: Harper Colophon, 1975. Print.

Howard, D. "The case for kingship in Deuteronomy and the Former Prophets." Westminster Theological Journal 52.1 (1990): 101-115.

Long, Thomas G. "The Fall of the House of Uzzah...and Other Difficult Preaching Texts.” Journal for Preachers 7.1 (1983): 13-19. Print.

Mendenhall, George E. and Gary A. Herion. “Covenant.” Anchor Bible Dictionary. Ed. David Noel Freedman. 1992. Volume 1, 1179-1202. Print.

Mettinger, T.N.D. "Yahweh Zebaoth.” Dictionary of Deities and Demons in the Bible. Eds. Karl van der Toorn, Bob Becking, Pieter W. van der Horst. 1999. 920-924. Print.

Penchansky, David. What Rough Beast? Images of God in the Hebrew Bible. Louisville: Westminster John Knox Press, 1999. Print.

Reddish, Mitchell G. "Bride of Christ.” Anchor Bible Dictionary. Ed. David Noel Freedman. 1992. Volume 1, 782. Print.

Seibert, Eric. Disturbing Divine Behavior: Troubling Old Testament Images of God. Minneapolis: Fortress Press, 2009. Print.

Stackert, Jeffrey. "Leviticus.” Oxford Encyclopedia of Books of the Bible. Ed. Michael D. Coogan. 2011. Volume 1, 573-581. Print.

Van der Toorn, Karl. "Yahweh." Dictionary of Deities and Demons in the Bible. Eds. Karl van der Toorn, Bob Becking, Pieter W. van der Horst. 1999. 910-919. Print.

Williamson, H.G.M. “Isaiah, Book of.” Dictionary of the Old Testament: Prophets. Eds. Mark J. Boda and J. Gordon McConville. 2012. 364-378. Print. 